\title{
The effects of tryptophan and pyridoxine supplied orally to nursing piglets on weight loss and social behavior after weaning
}

\section{Os efeitos do triptofano e da piridoxina fornecidos por via oral aos leitões em amamentação sobre a perda de peso e o comportamento social após o desmame}

\author{
Lucas Pimentel Bonagurio'; Leandro Dalcin Castilha²; Tiago Junior Pasquetti3; \\ Cleiton Pagliari Sangali4; Laura Marcela Dias Huepa1; Paulo Cesar Pozza ${ }^{2^{\star}}$
}

\section{Highlights}

91 caract - Scarce literature showing the optimal supplementation levels for nursing piglets.

Our study evaluated growth performance and social behavior.

99 caract - Evidences showing a decreasing weight loss on the first day after weaning.

99 caract - Treated animals visited the feeders more effectively in the overall period evaluated.

93 caract - No effects on growth performance were observed in the overall period evaluated.

\begin{abstract}
This study evaluated the effect of oral supplementation with tryptophan (Trp) and pyridoxine (Pyr) on the growth performance and social behavior of suckling piglets before and after weaning. At day 14 , six suckling piglets per sow were distributed into three treatments and allotted in a randomized block design, with eight replicates and two piglets per experimental unit. Treatments consisted of a Control - oral supplementation with L-alanine $(1.70 \mathrm{~g})$, D-glucose $(1.74 \mathrm{~g})$ and distilled water $(3.44 \mathrm{~mL})$; $\operatorname{Trp}$ - oral supplementation with $\operatorname{Trp}$ $(3.5 \mathrm{~g} / \mathrm{d})$ and distilled water; and $\operatorname{Trp}+$ Pyr - oral supplementation with $\operatorname{Trp}(3.5 \mathrm{~g} / \mathrm{d})+$ Pyr $(0.0095 \mathrm{~g} / \mathrm{d})$ and distilled water. Each treatment was supplied orally five times per day ( $2.5 \mathrm{~mL}$ each treatment), from 14 to 21 days old. Piglets were monitored continuously in the nursing phase for $24 \mathrm{~h}$ at 21, 28 and 33 days of age to assess the behavior (standing, lying, eating, socializing, sitting and drinking). Piglets receiving oral Trp + Pyr showed a decreased weight loss on the first day after weaning $(P=0.03)$. Performance was not affected $(P>0.05)$ by treatments in each studied period, such as in overall period ( 21 to 34 days) after weaning.
\end{abstract}

1 Drs., Universidade Estadual de Maringá, UEM, Maringá, PR, Brasil.E-mail: bonagurio@hotmail.com; lemondedelaura28@ hotmail.com

2 Profs. Drs., UEM, Maringá, PR, Brasil. E-mail: Idcastilha@uem.br; pcpozza@uem.br

3 Prof. Dr., Universidade Estadual do Mato Grosso do Sul, UFMS, Brasil. E-mail: pasquettizoo@yahoo.com.br

${ }^{4}$ Prof. Dr., Centro Universitário Grupo Integrado de Campo Mourão, IUCC, Campo Mourão, PR, Brasil. E-mail: sangalicp@ hotmail.com

* Author for correspondence

Received: May 16, 2020 - Approved: Aug. 24, 2020 
Piglets receiving Trp supplementation visited the feeders more frequently from days 21 to $22(P<0.01)$ and from days 28 to $29(P<0.02)$, as well as in the overall period $(P<0.01)$. It is concluded that high doses of tryptophan with or without high doses of pyridoxine, supplied orally to nursing piglets, reduced the weight loss on the first day after weaning and increased the frequency of visits to the drinkers on the first day after weaning and also to the feeders, mainly from weaning until 7 days after.

Key words: Aromatic amino acid. Performance. Post weaning stress.

\section{Resumo}

Este estudo avaliou o efeito da suplementação oral de triptofano (Trp) e piridoxina (Pyr) para leitões em aleitamento sobre o desempenho produtivo e comportamento social, antes e após o desmame. No $14^{\circ}$ dia de vida, seis leitões por porca foram divididos em três tratamentos e foram distribuídos em um delineamento experimental de blocos ao acaso, com oito repetições e dois leitões por unidade experimental (16 leitões/ tratamento). Os tratamentos foram os seguintes: Controle - suplementação oral de L-alanina $(1.70 \mathrm{~g})$, D-glicose (1.74 g) e água destilada (3.44 ml); Trp - suplementação oral de $\operatorname{Trp}(3.5 \mathrm{~g} / \mathrm{d}$ ) e água destilada; $\operatorname{Trp}+\operatorname{Pyr}-\operatorname{Trp}(3.5 \mathrm{~g} / \mathrm{d})+\operatorname{Pyr}(0.0095 \mathrm{~g} / \mathrm{d})$ e água destilada. Cada tratamento foi fornecido oralmente por cinco vezes ao dia ( $2.5 \mathrm{ml}$ em cada suplementação), do $14^{\circ}$ até o $21^{\circ}$ dia de idade. Durante a fase de creche os leitões foram monitorados durante 24 horas no $21^{\circ}, 28^{\circ}$ e $33^{\circ}$ dia de idade para avaliação do comportamento (em pé, deitado, comendo, sociabilizando, sentado e bebendo). Leitões suplementados oralmente com Trp + Pyr apresentaram uma redução na perda de peso $(P=0.03)$ no primeiro dia após o desmame. $O$ desempenho não foi influenciado $(P>0.05)$ pelos tratamentos nos períodos estudados, assim como no período total após o desmame (21 a 34 dias). Leitões que receberam suplementação de Trp, com ou sem Pyr, visitaram os comedouros mais frequentemente do $21^{\circ}$ ao $22^{\circ}$ dia $(P<0.01)$ e do $28^{\circ}$ ao $29^{\circ}(P<$ 0.02 ) assim como no período total $(P<0.01)$. Conclui-se que altas doses de Trp associadas ou não com altas doses de Pyr fornecidas oralmente aos leitões em aleitamento reduziram a perda de peso no primeiro dia após o desmame e aumentaram a frequência de visitas aos bebedouros no primeiro dia após o desmame e aos comedouros principalmente do desmame até 7 dias após ao desmame.

Palavras-chave: Aminoácido aromático. Desempenho. Estresse pós-desmame.

\section{Introduction}

The weaning of piglets is a period of intense stress due to several abrupt changes resulting from separation from the sows, a mix of different litters, a switch to a new environment, changes in diet, and others (Heo et al., 2013). These stress factors may cause negative effects on the gut and immune system of weaned pigs leading to important reductions in feed and water intake, followed many times by diarrhea.
As a result, reduced growth performance may be observed during the first week after weaning (Heo et al., 2013; Hwang et al., 2016; Pluske, Turpin, \& Kim, 2018). For this reason, many practices are important in reducing these negative effects after weaning, and some nutritional components may also help their mitigation.

Conceptually, dietary tryptophan (Trp) supplementation contributes to higher serotonin $(5-\mathrm{HT})$ concentration in the 
hypothalamus. 5-HT can regulate cortisol synthesis and reduce stress and aggressive behavior, contributing to the piglet's adaptation to a new environment (Höglund, $\varnothing$ verli, \& Winberg, 2019). Moreover, 5-HT may also modulate ghrelin and melatonin synthesis, which can affect appetite and sleep regulation (Vestlund et al., 2019). Furthermore, Trp, by the action of kynurenine and 5-HT, also stimulates the immune system, promoting a rise in the IgG and acute-phase protein concentrations (Jenkins, Nguyen, Polglaze, \& Bertrand, 2016; Lam, Garfield, Marston, Shaw, \& Heisler, 2010).

The synthesis of 5-HT in the brain depends on the active transport of Trp across the blood-brain barrier because it is oxidized to 5-HT in the central nervous system. Thus, a high Trp intake results in an increased 5 -HT concentration in the blood plasma and pituitary gland (Shen, Voilqué, Odle, \& Kim, 2012b). Pyridoxine (Pyr) may increase 5-HT concentration by acting as a cofactor in its synthesis (Le Floc'h, Otten, \& Merlot, 2011), as it catalyzes some biochemical pathways of 5-HT synthesis.

In this regard, the addition of Trp with or without Pyr to the diet of suckling piglets may promote a reduction in stress factors, resulting in an improvement in the development of the intestinal and immune systems (Shen, Voilqué, Odle, \& Kim, 2012a; Shen, Coffey, \& Kim, 2015). It is hypothesized that oral supplementation to piglets with high doses of Trp, with or without with high doses of Pyr, may influence consumption and social behavior before and after weaning, resulting in improvements in their growth performance.

However, there is a lack of information concerning the supplementation with Trp and Pyr for suckling piglets and its effects after weaning. For this reason, the objective of this study was to evaluate the effect of oral supplementation of Trp and Pyr on the growth performance and social behavior of suckling piglets before and after weaning.

\section{Materials and Methods}

The experimental procedures were approved by the Animal Care and Use Committee of the State University of Maringá (Protocol 3766220417).

The experiment was carried out in the Swine Facilities of the State University of Maringá. The suckling piglets were supplemented orally five times a day during the nursing phase (14-21 d of age) with one of the following treatments: Control - oral supplementation with L-alanine $(1.70 \mathrm{~g})$, D-glucose $(1.74 \mathrm{~g})$ and distilled water $(3.44 \mathrm{~mL})$; Trp - oral supplementation with $\operatorname{Trp}(3.5 \mathrm{~g} / \mathrm{d})$ and distilled water; Trp + Pyr - oral supplementation with $\operatorname{Trp}(3.5 \mathrm{~g} / \mathrm{d})+\operatorname{Pyr}(0.0095 \mathrm{~g} / \mathrm{d})$ and distilled water. The piglets were allotted into a randomized block design consisting of the three aforementioned treatments, eight replicates and two piglets per experimental unit, totaling 48 piglets of $4.86 \pm 0.48 \mathrm{~kg}$ average initial weight.

Six piglets (Landrace $x$ Large White) from the same litter, of similar body weight (BW), were paired (a male and a female) and assigned to a treatment. Initial BW and the piglets being from the same litter were the criteria adopted to select the animals to assign to the treatments, consisting of a replicate.

L-Alanine and D-glucose were used in the Control treatment to equalize the concentrations of nitrogen and metabolizable energy presented by the other treatments (Trp 
and Trp + Pyr). L-Alanine was used in the Control treatment because it is non-toxic, does not show biological functions, and is extensively catabolized (Mateo, Wu, Moon, Carroll, \& Kim, 2008; Ren et al., 2019).

L-Alanine, D-glucose, L-Trp and Pyr were firstly diluted in distilled water to facilitate the oral supplementation and to set up the same volume (i.e. milliliters) to be supplied for each treatment $(2.5 \mathrm{~mL}$ each supplementation, totaling $12.5 \mathrm{~mL} /$ piglet/day). All treatments were supplied orally at every $2 \mathrm{~h}$, starting at 8 am and finishing at $4 \mathrm{pm}$, comprising the daylight period for 5-HT synthesis, using disposable syringes with a pre-set volume of $2.5 \mathrm{~mL}$ for each meal, as aforementioned.

Piglets received a standard commercial diet from $7 \mathrm{~d}$ of age until weaning. They received a standard commercial diet in the nursing phase (21-35 d of age).

During the nursing phase, the piglets assigned to treatments remained in the same farrowing crate together with the born litter. The farrowing barn was equipped with farrowing crates with frontal feeders, nippletype drinkers and a dedicated cooling system directed toward the head of each sow. In the farrowing crates, the piglets had free access to a warming box and specific nipple-type drinkers and self-feeders.

Each piglet subjected to the same treatment during the nursing phase were moved at weaning to the same experimental unit in the nursery facility, which contained suspended pens, curtains and a fan system. Each pen was equipped with a partially slatted floor covering $1 / 3$ of the pen, electric heating, a front feeder and a nipple-type drinker.

Piglets were weighed at the beginning of the oral supplementation (at $14 \mathrm{~d}$ ) and weaning
(21 d), to evaluate the BW and average daily gain (ADG) during this 7-d supplementation period. The $B W, A D G$, average daily feed intake (ADFI), and feed gain ( $F: G$ ) were also evaluated from weaning to $35 \mathrm{~d}$ of age. ADG, ADFI and $F: G$ were calculated as $A D G=$ weight gain/days, $A D F I=$ feed intake/days, $F: G=A D F I / A D G$.

The social behavior of each piglet was recorded weekly (from 21 to 22,28 to 29 , and 33 to $34 \mathrm{~d}$ of age), for $24 \mathrm{~h}$, using a ceilingmounted camera (Panasonic WV-CD110AE, Matsushita Electric Industrial Co. Ltd., Osaka, Japan) attached to a digital video recording system (Geovision ${ }^{\circledR}$ GV800 board attached to a desktop). Scan sampling, as described by P. Martin and Bateson (1993), was used to evaluate the time-budget of pigs' behavior in each nursery pen.

A previously trained observer watched all the recorded videos to score the behaviors, and data were analyzed by classifying the behaviors as eating, drinking, socializing, sitting, standing, and lying (Shen et al., 2012a). The daily behavior was evaluated by instantaneous sampling performed every five minutes during the full period (24 h), obtaining the frequencies (\%) that each behavior was expressed by each piglet.

Growth performance in the nursing and nursery phase, as well as the social behavior data in the nursery phase, were evaluated statistically in a randomized block design with three treatments and eight replicates. The initial body weight was used as a covariate in the growth performance evaluation.

Data were analyzed by the Mixed procedure of the Statistical Analyses System ${ }^{\circledast}$ [SAS] (2019), the LSMEANS procedure was used to calculate the meanvalues, and the PDIFF option was used to generate comparisons 
between treatments. The frequencies obtained for the social behavior were firstly transformed to $\log (X+1)$, due to their not showing normal distribution. The Student-Newman-Keuls test, due to the intermediate rigor between Tukey and Dunnett, was used to identify statistical differences that were considered at $\mathrm{P}<0.05$.

\section{Results and Discussion}

The growth performance of nursing piglets ( 14 to $21 \mathrm{~d}$ ) was similar $(P>0.05$ ) between the studied treatments (Table 1). However, piglets receiving the oral supplementation of Trp showed a lower weight loss $(P=0.03)$ than those receiving the Control treatment (Table 1 ) on the first day after weaning (weight at $22 \mathrm{~d}$ ). No differences $(P>0.05)$ were observed in BW $A D F I, A D G$, and $F: G$ at the remaining periods, indicating that the effects of high Trp doses, supplied orally during the $7 \mathrm{~d}$ before weaning, did not providing a residual effect to contribute to the subsequent growth performance.

Trp is known to be involved in several physiological functions (Le Floc'h et al., 2011). It plays a central role in protein synthesis because it is the main protein component of the piglet's body (Mou, Yang, Yin, \& Huang, 2019. Moreover, Trp is also the precursor for the synthesis of pituitary $5-\mathrm{HT}$, which regulates several processes, such as voluntary feed intake (Höglund et al., 2019; Martin, Osadchiy, Kalani, \& Mayer, 2018), mood (Quintero-Villegas
\& Valdés-Ferrer, 2020; Martin, Osadchiy, Kalani, \& Mayer, 2016), and social and physiology behaviors (Poletto, Kretzer, \& Hötzel, 2014).

Accordingly, increasing dietary Trp levels can enhance the hypothalamic 5-HT concentration (Shen et al., 2012b; Young, 2013) which can possibly reduce aggressive behavior and the social and physiological stress in piglets associated with the formation and maintenance of social hierarchies and competition follow the mixing of piglets with new pen-mates on weaning and partially explain the lower weight loss in the first day after weaning observed in this experiment (Table 1).

The associated supplementation with Trp and Pyr also resulted in a lower weight loss compared with supplementing with high doses of Trp only (Table 1). In this sense, the lowest weight loss at the first day after weaning of piglets orally supplemented with Trp + Pyr during the week before weaning, may also be associated with the action of Pyr in the metabolism of Trp to synthesize 5-HT because there are two Pyr dependent enzymes in this pathway: a mono-oxygenase and a decarboxylase (Liang, Han, Tan, Ding, \& Li, 2019). Thus, it is possible that the high availability of Pyr may improve the action of Trp as the precursor for 5-HT synthesis in the brain, evidence that studies in this area need to be carried out for a better understanding of this process in pigs. 
Table 1

Oral supplementation of tryptophan (Trp) and pyridoxine (Pyr) for nursing piglets on the nursing (from 14 to $21 \mathrm{~d}$ ) and post-weaning (from 21 to $34 \mathrm{~d}$ ) performance

\begin{tabular}{|c|c|c|c|c|c|}
\hline \multirow[b]{2}{*}{ Parameter } & \multicolumn{3}{|c|}{ Treatments } & \multirow[t]{2}{*}{$P$ value } & \multirow[t]{2}{*}{ SEM $^{1}$} \\
\hline & Control & Trp & Trp+Pyr & & \\
\hline \multicolumn{6}{|c|}{ Bodyweight (BW) (Kg) } \\
\hline Initial BW - $14 d$ & 4.82 & 4.88 & 4.87 & 0,81 & 0.10 \\
\hline BW $21 \mathrm{~d}$ & 6.46 & 6.48 & 6.49 & 0,78 & 0.19 \\
\hline BW 22 d & $6.16^{c}$ & $6.20^{\mathrm{ab}}$ & $6.23^{\mathrm{a}}$ & 0.03 & 0.18 \\
\hline BW $28 d$ & 6.85 & 6.92 & 7.02 & 0,66 & 0.19 \\
\hline BW $34 \mathrm{~d}$ & 8.83 & 8.97 & 9.04 & 0,81 & 0.26 \\
\hline \multicolumn{6}{|c|}{ Weight loss (g) } \\
\hline 21 to $22 \mathrm{~d}$ & $300^{a}$ & $279^{b}$ & $263^{c}$ & 0.03 & 7.80 \\
\hline \multicolumn{6}{|c|}{$\mathrm{ADG}^{2} \cdot \mathrm{g} / \mathrm{d}$} \\
\hline 14 to $21 \mathrm{~d}$ & 246.68 & 252.15 & 244.00 & 0,68 & 12.34 \\
\hline 21 to $28 d$ & 55.82 & 63.49 & 75.61 & 0,63 & 19.16 \\
\hline 28 to $34 \mathrm{~d}$ & 331.07 & 341.67 & 336.07 & 0,69 & 19.11 \\
\hline 21 to $34 \mathrm{~d}$ & 182.71 & 191.86 & 195.85 & 0,87 & 14.22 \\
\hline \multicolumn{6}{|c|}{$\mathrm{ADFI}^{3} \cdot \mathrm{g}$} \\
\hline 21 to $28 d$ & 143,27 & 147,14 & 173.27 & 0,44 & 9.54 \\
\hline 28 to $34 \mathrm{~d}$ & 473.57 & 473.10 & 472.71 & 0,99 & 20.03 \\
\hline 21 to $34 \mathrm{~d}$ & 306.70 & 313.46 & 311.47 & 0,93 & 12.59 \\
\hline \multicolumn{6}{|c|}{$F: G^{4} \cdot g / g$} \\
\hline 21 to $28 d$ & 2.38 & 2.36 & 2,38 & 0,30 & 0.05 \\
\hline 28 to $34 \mathrm{~d}$ & 1.48 & 1.44 & 1.46 & 0,85 & 0.06 \\
\hline 21 to $34 \mathrm{~d}$ & 1.80 & 1.79 & 1.71 & 0,56 & 0.10 \\
\hline
\end{tabular}

${ }^{1}$ Standard error of the mean.

${ }^{2}$ Average daily gain.

${ }^{3}$ Daily feed intakes.

${ }^{4}$ Feed:gain ratio.

The weight loss on the first day after weaning also affected the BW at $22 \mathrm{~d}$ of age, showing that Trp + Pyr supplementation was more effective in providing a better BW compared to the Control treatment, but Trp supplementation showed a similarity with the studied treatments (Table 2). As aforementioned, Pyr plays an important role in the Trp pathway to synthesize 5-HT and protein
(Mund et al., 2020) and may be related to the results obtained in this study.

5-HT plays several roles in metabolism associated with feed intake, melatonin synthesis and social behavior (KałużnaCzaplińska, Gątarek, Chirumbolo, Chartrand, \& Bjørklund, 2019). In this way, the increased frequency of visits to the drinkers and feeders $(P=0.01)$ during the $24 \mathrm{~h}$ after weaning of 
piglets orally supplemented with Trp or Trp + Pyr (Table 2) may be associated with higher 5-HT synthesis in the brain (Shen et al., 2012a). Nevertheless, it could also be due to reductions in some stress factors resulting in improved intestine and immune systems, which may also be associated with the lower weight loss on the first day after weaning of piglets receiving oral supplementation with Trp + Pyr (Table 1).

\section{Table 2}

Oral supplementation of tryptophan (Trp) and pyridoxine (Pyr) for nursing piglets on the post-weaning behavior (from 21 to $34 \mathrm{~d}$ ), expressed in Log $(X+1)$ and percentages

\begin{tabular}{|c|c|c|c|c|c|}
\hline \multirow{2}{*}{ Parameter } & \multicolumn{3}{|c|}{ Treatments } & \multirow[t]{2}{*}{$P$ value } & \multirow[t]{2}{*}{ SEM $^{1}$} \\
\hline & Control & Trp & Trp+Pyr & & \\
\hline \multicolumn{6}{|c|}{21 to $22 d$} \\
\hline Standing & $1.51(31.58)^{*}$ & $1.48(30.20)$ & $1.44(27.47)$ & 0,39 & 0.02 \\
\hline Lying & 1.81(63.99) & $1.80(62.40)$ & $1.82(65.65)$ & 0,68 & 0.01 \\
\hline Eating & $0.33^{c}(1.43)$ & $0.64^{a}(3.68)$ & $0.54^{b}(2.81)$ & 0.01 & 0.05 \\
\hline Socializing & $0.29(1.41)$ & $0.34(1.86)$ & $0.31(1.84)$ & 0,73 & 0.07 \\
\hline Sitting & $0.33(1.21)$ & $0.34(0.94)$ & $0.31(1.17)$ & 0,68 & 0.03 \\
\hline Drinking & $0.12^{c}(0.37)$ & $0.27^{\mathrm{ab}}(0.92)$ & $0.3(1.06)$ & 0.01 & 0.03 \\
\hline \multicolumn{6}{|c|}{28 to $29 \mathrm{~d}$} \\
\hline Standing & $0.95(8.63)$ & $0.89(6.89)$ & $0.86(6.45)$ & 0,22 & 0.03 \\
\hline Lying & 1.88(74.78) & 1.86(71.70) & 1.87(74.38) & 0,19 & 0.01 \\
\hline Eating & $1.18^{c}(14.88)$ & $1.29^{a}(19.27)$ & $1.25^{\mathrm{ab}}(17.83)$ & 0.02 & 0.03 \\
\hline Socializing & $0.17(0.60)$ & $0.22(0.84)$ & $0.13(0.37)$ & 0,79 & 0.03 \\
\hline Sitting & $0.16(0.64)$ & $0.14(0.64)$ & $0.13(0.47)$ & 0,54 & 0.05 \\
\hline Drinking & $0.16(0.47)$ & $0.20(0.64)$ & $0.16(0.50)$ & 0,72 & 0.02 \\
\hline \multicolumn{6}{|c|}{33 to $34 d$} \\
\hline Standing & $1.07(10.78)$ & $1.04(10.19)$ & $1.03(9.92)$ & 0,47 & 0.02 \\
\hline Lying & $1.85(70.11)$ & 1.83(67.36) & $1.84(68.43)$ & 0,27 & 0.01 \\
\hline Eating & $1.26(18.02)$ & $1.31(20.46)$ & $1.28(19.27)$ & 0,23 & 0.03 \\
\hline Socializing & $0.15(0.47)$ & $0.15(0.50)$ & $0.24(1.14)$ & 0,40 & 0.04 \\
\hline Sitting & $0.07(0.17)$ & $0.13(0.47)$ & $0.16(0.52)$ & 0,20 & 0.03 \\
\hline Drinking & $0.14(0.45)$ & $0.28(1.02)$ & $0.23(0.72)$ & 0,20 & 0.03 \\
\hline \multicolumn{6}{|c|}{21 to 34} \\
\hline Standing & $1.25(17.00)$ & $1.22(15.76)$ & $1.19(14.61)$ & 0,28 & 0.01 \\
\hline Lying & $1.85(69.62)$ & 1.83(67.15) & $1.85(69.49)$ & 0,34 & 0.01 \\
\hline Eating & $1.08^{c}(11.44)$ & $1.18^{a}(14.47)$ & $1.14^{\mathrm{ab}}(13.30)$ & $<0.01$ & 0.03 \\
\hline Socializing & $0.25(0.83)$ & $0.27(1.07)$ & $0.26(1.12)$ & 0,93 & 0.04 \\
\hline Sitting & $0.21(0.68)$ & $0.20(0.69)$ & $0.22(0.72)$ & 0,88 & 0.03 \\
\hline Drinking & $0.15(0.43)$ & $0.26(0.86)$ & $0.24(0.76)$ & 0.06 & 0.02 \\
\hline
\end{tabular}

${ }^{1}$ Standard error of the mean.

*Values in parentheses represent the behavior frequencies as percentages. 
The increased frequency of visits to the feeders of piglets supplemented with Trp $(P=0.02)$, from 28 to $29 d$ (Table 2), may also be associated with the lasting effects of increased 5-HT synthesis resulting from the high amount of Trp and the higher BW after $22 \mathrm{~d}$ shown by piglets in this experiment. Interestingly, no effects of Trp or Trp + Pyr supplementation were observed on the growth performance after 28 days of age, showing a short period of action on the performance traits after weaning (24 h), as aforementioned, which may probably be related to the extensive catabolism of 5-HT in the brain (Lowery, Woulfe, \& Kilic, 2019; Singh, Fletcher, Li, Rusch, \& Kilic, 2013).

Another hypothesis is that Trp or Trp + Pyr supplementation only increased the frequency of visits to the feeders but did not affect the amount of diet ingested by the piglets during the first week after weaning because, despite the numerical values of ADG between the studied treatments from 21 to 28 $d$, no differences $(P>0.05)$ were observed for this parameter.

The obtained results showed an increased frequency of visits to feeders until 7 $d$ after weaning $(P<0.01)$ and also in the overall period $(P<0.01)$, but there was only a trend $(P$ $=0.06$ ) in the increase in visits to the drinkers in the overall period shown by piglets receiving Trp or Trp + Pyr. This is relevant because increased visits to the drinkers can increase the ADFI and help mitigate the effects caused by changes in the environment and diet after weaning (Middelkoop, Costermans, Kemp, \& Bolhuis, 2019). However, no differences $(P>0.05)$ were observed for the behavioral parameters of standing, lying, sitting and socializing.

On the first day after weaning ( 21 to $22 \mathrm{~d}$ ) an increased frequency of visits to the feeders and drinkers $(P=0.01)$ was also observed for piglets receiving oral Trp supplementation, with or without Pyr, during the nursing phase (Table 2), showing that oral supplementation with Trp or Trp + Pyr for nursing piglets (from 14 to $21 \mathrm{~d}$ of age) increased the search for food and water immediately after weaning. Thus, higher dietary Trp levels probably increase hypothalamic 5-HT concentration in order to reduce aggressive behavior and promote improved search for water and food by piglets after weaning (Liu, Shi, Liu, \& Shan, 2013; Liu, Zhang, Li, Yan, \& Zhang, 2019).

The increased frequency of visits to the drinkers may be associated with the increased feed intake; however, despite the increased frequency of visits to the feeders, the ADFI was not affected by treatments (Table 1). Evaluating increased levels of Trp for nursing pigs, Shen et al. (2012b) observed a linear increase in drinking behavior, reporting that this may be associated with an increase in $5-\mathrm{HT}$ production in the brain, but they did not observe effects on eating behavior.

Piglets supplemented with Trp, associated or not with Pyr, showed a higher frequency of eating behavior from 28 to 29 days of age when compared to piglets receiving the Control treatment. These results, associated with eating behavior data on the first day after weaning, affected the overall period (from 21 to 34 days of age) in which piglets orally supplemented with Trp, or Trp + Pyr, attended the feeder more frequently $(P=0.001)$.

The oral supplementation with Trp + Pyr, about five times higher than the nutritional requirements proposed by the National Research Council [NRC] (2012) for piglets from 5 to $7 \mathrm{~kg} \mathrm{BW}$, seems to affect the piglets' social behavior, as observed in this study. Furthermore, new studies are necessary to 
elucidate the optimum doses and suitable supplementation time to promote different effects after weaning and improve growth performance.

Additionally, oral Trp supplementation for nursing piglets from 14 to 21 days of age and its association with Pyr is effective in reducing the weight loss on the first day after weaning, increasing the frequency of visits to drinkers on the first day after weaning and also to the feeders until seven days after weaning and during the overall period (21 to 34 days).

Pyr, acting as an enzymatic cofactor in some metabolic Trp pathways (Le Floc'h et al., 2011), probably affected some of the parameters evaluated in this study. Moreover, supplementation with Trpand Trp + Pyr probably raised the 5-HT concentration (Höglund et. al, 2019), enhancing the gut development and also the immune system (Jayaraman, Htoo, \& Nyachoti, 2017) and helping to mitigate the after-weaning stress. In this sense, the obtained results would support future research with a new perspective of studying other metabolic parameters to evaluate the interaction between Trp and Pyr and also their isolated effects on growth performance, gut development, hormonal synthesis, antioxidant status and the immune system.

\section{Conclusion}

It is concluded that high doses of tryptophan with or without high doses of pyridoxine supplied orally to nursing piglets reduced the weight loss on the first day after weaning, and increased the frequency of visits to drinkers on the first day after weaning and to the feeders mainly from weaning until 7 days after.

\section{Acknowledgments}

The research was co-funded by State University of Maringá, Conselho Nacional de Desenvolvimento Científico e Tecnológico (CNPq, Brazil) and Coordenação de Aperfeiçoamento de Pessoal de Nível Superior - Brasil (CAPES).

\section{References}

Heo, J. M., Opapeju, F. O., Pluske, J. R., Kim, J. C., Hampson, D. J., \& Nyachoti, C. M. (2013). Gastrointestinal health and function in weaned pigs: a review of feeding strategies to control post weaning diarrhoea without using in-feed antimicrobial compounds. Journal of Animal Physiology and Animal Nutrition, 97(2), 207-237. doi: 10.1111/ j.1439-0396.2012. 01284.x

Höglund, E., Øverli, Ø., \& Winberg, S. (2019). Tryptophan metabolic pathways and brain serotonergic activity: a comparative review. Frontiers in Endocrinology, 10(1), 1-11. doi: 10.3389/fendo.2019.00158

Hwang, H. S., Lee, J. K., Eom, T. K., Son, S. H., Hong, J. K., Kim, K. H., \& Rhim, S. J. (2016). Behavioral characteristics of weaned piglets mixed in different groups. Asian-Australasian Journal of Animal Sciences, 29(7), 1060-1064. doi: 10.5713/ ajas.15.0734

Jayaraman, B., Htoo, J. K., \& Nyachoti, C. M. (2017). Effects of different dietary tryptophan: lysine ratios and sanitary conditions on growth performance, plasma urea nitrogen, serum haptoglobin and ileal histomorphology of weaned pigs. Animal Science Journal, 88(5), 763-771. doi: 10.1111/asj.12695 
Jenkins, T. A., Nguyen, J. C., Polglaze, K. E., \& Bertrand, P. P. (2016). Influence of tryptophan and serotonin on mood and cognition with a possible role of the gut-brain axis. Nutrients, 8(1), 1-15. doi: 10.3390/nu8010056

Kałużna-Czaplińska, J., Gątarek, P., Chirumbolo, S., Chartrand, M. S., \& Bjørklund, G. (2019). How important is tryptophan in human health? Critical Reviews in Food Science and Nutrition, 59(1), 72-88. doi: 10.1080/10408398.2017.1357534

Lam, D. D., Garfield, A. S., Marston, O. J., Shaw, J., \& Heisler, L. K. (2010). Brain serotonin system in the coordination of food intake and body weight. Pharmacology Biochemistry and Behavior, 97(1), 84-91. doi: 10.1016/j.pbb.2010.09.003

Le Floc'h, N., Otten, W., \& Merlot, E. (2011). Tryptophan metabolism, from nutrition to potential therapeutic applications. Amino Acids, 41(5), 1195-1205. doi: 10.1007/ s00726-010-0752-7

Liang, J., Han, Q., Tan, Y., Ding, H., \& Li, J. (2019). Current advances on structure-function relationships of pyridoxal 5-phosphatedependent enzymes. Frontiers in Molecular Biosciences, 6(1), 1-21. doi: 10.33 89/fmolb.2019.00004

Liu, H. W., Shi, B. M., Liu, D. S., \& Shan, A. S. (2013). Supplemental dietary tryptophan modifies behavior, concentrations of salivary cortisol, plasma epinephrine, norepinephrine and hypothalamic 5-hydroxytryptamine in weaning piglets. Livestock Science, 151(2-3), 213-218. doi: 10.1016/j.livsci.2012. 11.003

Liu, J., Zhang, Y., Li, Y., Yan, H., \& Zhang, H. (2019). L-tryptophan enhances intestinal integrity in diquat-challenged piglets associated with improvement of redox status and mitochondrial function. Animals, 9(5), 1-22. doi: 10.3390/ani9050266
Lowery, C. L., Woulfe, D., \& Kilic, F. (2019). Responses of plasma catecholamine, serotonin, and the platelet serotonin transporter to cigarette smoking. Frontiers in Neuroscience, 13(1), 1-7. doi: 10.3389/ fnins.2019.00032

Martin, C. R., Osadchiy, V., Kalani, A., \& Mayer, E. A. (2018). The brain-gut-microbiome axis. Cellular and Molecular Gastroenterology and Hepatology, 6(2), 133-148. doi: 10.1016/j.jcmgh.2018.04.003

Martin, P., \& Bateson, P. P. G. (1993). Measuring behaviour: an introductory guide (2nd ed.). Cambridge: Cambridge University Press.

Martin, C. R., Osadchiy, V., Kalani, A., \& Mayer, D. (2016). Mood, food, and cognition: role of tryptophan and serotonin. Current Opinion in Clinical Nutrition \& Metabolic Care, 19(1), 55-61. doi: 10.1097/ MC0.0000000000000237

Mateo, R. D., Wu, G., Moon, H. K., Carroll, J. A., \& Kim, S. W. (2008). Effects of dietary arginine supplementation during gestation and lactation on the performance of lactating primiparous sows and nursing piglets. Journal of Animal Science, 86(4), 827835. doi: 10.2527/jas.2007-0371

Middelkoop, A., Costermans, N., Kemp, B., \& Bolhuis, J. E. (2019). Feed intake of the sow and playful creep feeding of piglet's influence piglet behaviour and performance before and after weaning. Scientific Reports, 9(1), 1-13. doi: 10.1038/ s41598-019-52530-w

Mou, Q., Yang, H. S., Yin, Y. L., \& Huang, P. F. (2019). Amino Acids Influencing Intestinal Development and Health of the Piglets. Animals, 9(6), 302-313.

Mund, M. D., Riaz, M., Mirza, M. A., Rahman, Z. U., Mahmood, T., Ahmad, F., \& Ammar, A. (2020). Effect of dietary tryptophan supplementation on growth performance, 
immune response and anti oxidant status of broiler chickens from 7 to 21 days. Veterinary Medicine and Science, 6(1), 4853. doi: 10.10 02/vms3.195

National Research Council (2012). Nutrient requirements of swine. New York: National Academies Press.

Pluske, J. R., Turpin, D. L., \& Kim, J. C. (2018). Gastrointestinal tract (gut) health in the young pig. Animal Nutrition, 4(2), 187-196. doi: 10.1016/j.aninu.2017.12.004

Poletto, R., Kretzer, F. C., \& Hötzel, M. J. (2014). Minimizing aggression during mixing of gestating sows with supplementation of a tryptophan-enriched diet. Physiology \& Behavior, 132(1), 36-43. doi: 10.10 16/j. physbeh.2014.04.043

Quintero-Villegas, A., \& Valdés-Ferrer, S. I. (2020). Role of 5-HT 7 receptors in the immune system in health and disease. Molecular Medicine, 26(1), 1-8. doi: 10.1186/s10020-019-0126-x

Ren, M., Cai, S., Zhou, T., Zhang, S., Li, S., Jin, E.,... Qiao, S. (2019). Isoleucine attenuates infection induced by $E$. coli challenge through the modulation of intestinal endogenous antimicrobial peptide expression and the inhibition of the increase in plasma endotoxin and $\mathrm{IL}-6$ in weaned pigs. Food \& Function, 10(6), 3535-3542. doi: 10.1039/C9FO00218A

Shen, Y. B., Coffey, M. T., \& Kim, S. W. (2015). Effects of short-term supplementation of I-tryptophan and reducing large neutral amino acid along with I-tryptophan supplementation on growth and stress response in pigs. Animal Feed Science and Technology, 207(1), 245-252. doi: 10.1016/j.anifeedsci. 2015.06.020
Shen, Y. B., Voilqué, G., Kim, J. D., Odle, J., \& Kim, S. W. (2012a). Effects of increasing tryptophan intake on growth and physiological changes in nursery pigs. Journal of Animal Science, 90(7), 22642275. doi: 10.2527/jas.2011-4203

Shen, Y. B., Voilqué, G., Odle, J., \& Kim, S. W. (2012b). Dietary L-tryptophan supplementation with reduced large neutral amino acids enhances feed efficiency and decreases stress hormone secretion in nursery pigs under socialmixing stress. The Journal of Nutrition, 142(8), 1540-1546. doi: 10.3945/jn. 112.163824

Singh, P., Fletcher, T. W., Li, Y., Rusch, N. J., \& Kilic, F. (2013). Serotonin uptake rates in platelets from angiotensin II-induced hypertensive mice. Health, 5(4A), 31-39. doi: 10.4236/health.2013.54A005

Statistical Analyses System ${ }^{\circledast}$ (2019). University Edition @SAS Institute Inc. Retrieved from https://www.sas. com/en_us/software/ university-edition.html

Vestlund, J., Winsa-Jörnulf, J., Hovey, D., Lundström, S., Lichtenstein, P., Anckarsäter, H.,... Jerlhag, E. (2019). Ghrelin and aggressive behaviours Evidence from preclinical and human genetic studies. Psychoneuroendocrinology, 104(1), 8088. doi: 10.1016/j.psyneuen.2019.02.020

Young, S. N. (2013). The effect of raising and lowering tryptophan levels on human mood and social behaviour. Philosophical Transactions of the Royal Society B: Biological Sciences, 368(1615), 1-9. doi: 10.1098/rstb.2011.0375 
